Asia Minor" (p. 383 , etc.) ; and to the author's visitation of the Coptic monastery of St. Anthony near the Red Sea-a village of sixty houses, in two streets - with its gentle-eyed, hospitable, intelligent monks, and its gardens, guest-house, stores, stables, mill, swimming-bath, oil-press, and churches.

The reader should also turn to the studies of Arab and Kurdish humanity-the refinement and intelligence of the one, balanced by the simplicity, energy, and dare-devilry of the other; to the descriptions of the tumbled grandeur of the Alps of Kurdistan; and to the appendix on the Kurdish tribes, their distribution, numbers, and special features, past or present-this last an excellent piece of work. Finally, he may welcome the writer's appreciation of the merits of Muhammadan life and faith in Turkey, with its gleams of social religion "most admirable to me," of the reality and strength of Muslim devotion, and of the unconscious brotherhood of Islam (e.g., pp. 383-5, etc. ; $390 ; 5^{23}$, etc.).

\section{FRENCH VIEWS OF THE SYNTHETIC DYE PROBLEM.}

IN a recent issue of the Revue Scientifique 1 (January 8) Dr. Wahl, the director of the laboratory of the Poirrier works, who is already well known to English chemists as the author of a very readable text-book on organic dyestuffs, deals with the problem of the manufacture of these dyes in France.

In the historical summary of the causes which led to the decline of the dye industry in England and France, Dr. Wahl emphasises the importance of systematic scientific research as an aid to technical progress. This aid to the industrial chemist is illustrated by the work carried out by Hofmann at the College of Chemistry in London during the first twenty years of the youthful industry. An application to coal tar dyes of the purely scientific research on organic amines led to the discovery of Hofmann's violet and similar colours. The return of this scientific investigator to Germany in 1865 shifted the centre of gravity of the colour industry, for subsequently many of the master's German pupils also left the country and transferred to German factories the practical experience they had originally gained in English works. After a magnificent start the French dye industry came to a standstill, and this halt was prolonged by the disasters of the Franco-German war.

The next important development after 1870 was the production of acid azo-dyes, a discovery which was made simultaneously by French and German workers. In view of the immense range of possible combinations the French firm of Poirrier decided not to patent the new dyes, but in a few months Hofmann published in the Berichte the composition of the Poirrier oranges and their method of preparation. The systematic investigation of azo-dyes was a task admirably suited to the German temperament. The preparation and testing of the enormous number of possible combinations required the collaboration of very large staffs of specially trained chemists, whose co-ordinated work on the extensive series of azodyes and their generators was a truly gigantic achievement.

This application of the attack by massed battalions to problems of industrial chemistry stood the German colour firms in good stead as other developments arose. For when the French chemist, Vidal, discovered his well-known sulphur black in 1896, the German factories immediately mobilised their armies of chemists and, in the Mackensen drive which ensued, they maintained a steady bombardment of two patents per week, in this class of dyes alone, for a period of eighteen months, with the result that the domain of sulphide dyes was practically annexed by the German colour-makers. This success has been repeated in many other branches of the colour trade, whole sections of which became German monopolies.

First among the scientific causes of this German predominance must be placed the rapid growth in the middle of the nineteenth century of the study of practical organic chemistry, and secondly we have the evolution of large technical laboratories having a scientific organisation of the highest order. Under the leadership of Bernthsen, Bohn, Duisberg, Sandmeyer, and others, continuity of effort, organisation of research, orderly arrangement of references and bibliography produced a sum total of intimate practical knowledge of the subject which could not have been gained in any other less methodical way. This co-ordination of effort in the German colour industry gives rise to 300 patent applications per annum, so that practically each day ushers in a discovery of sufficient importance to justify protection.

Among the commercial factors of this success the most striking is the employment by each German firm of a staff of technically trained representatives who visit the users of their products, demonstrating new methods of dyeing, anticipating the wants and difficulties of their clients, and collecting for their employers a valuable fund of information on the trading side of the business.

So much reliance is being founded in England on the prospects offered by a systematic boycott of German goods after the war that Dr. Wahl's views on this subject are worthy of note. As a professor of the beleaguered University of Nancy he can scarcely be suspected of pro-German bias, and yet he writes as follows:-

In order to sell, one must be prepared to offer the goods at a price equal to or lower than that of the competitors. For I do not think one should attribute t. $)$ the question of sentiment an importance which it does not possess. If one may suppose that the unpopularity of our enemies will produce, after the war, a period of hesitation in the renewal of commercial relations with them, it would be presumptuous to think that personal interest will not, sooner or later, prevail over other considerations. It will then be essential to be in a position to offer the dyes at prices approximately equal to those quoted by the Germans. 
In connection with the British scheme, it has recently been stated that "many hundreds of men, drawn from other occupations, have become chemical workers, and are making more money than they ever earned before." Although it is satisfactory to know that these new-comers in the dye field are already reaping a golden harvest, yet it must be admitted that the existing conditions are exceptional, even in an enterprise largely subsidised by the State. The ultimate justification of this good fortune will be the capacity to meet the foreign rival, whether German or American, with dyes of equal tinctorial value at even prices. As regards the French problem, Dr. Wahl is under no illusions as to an easy victory. He warns his compatriots that in this competition, as in the war, the essential requirements are stupendous efforts, much expenditure of capital, and even more of time.

SIR WILLIAM TURNER, K.C.B., F.R.S.

SIR WILLIAM TURNER, vice-chancellor and $\checkmark$ principal of the University of Edinburgh, died on Tuesday, February I 5, in the eighty-fourth year of his age. His much-lamented death was unexpected. Almost to the day preceding the last illness he had been engaged in university duties, to which his whole life had been devoted. Although for several days previously he had been suffering from a recurrence of slight symptoms of gastric derangement, which for several years had been the one "thorn in the flesh" of an otherwise singularly strong and robust constitution, they had not prevented him from engaging in university work. A profuse gastric hæmorrhage, however, occurred early on Sunday morning, February I3, which produced collapse, soon followed by a painless oblivion, terminating in the final rest of death.

His record is a great one of services to his university and to the cause of education. A distinguished student of St. Bartholomew's Hospital, London, he went to Edinburgh on the invitation of the renowned Prof. Goodsir to assume the office of demonstrator of anatomy. So successful was he in this office and so meritorious were his early contributions to anatomical knowledge that on the death of Goodsir in $x 867$, he was, by universal approval, appointed to succeed him as professor of anatomy. He brilliantly justified expectation during his thirty-six years of tenure of the chair. Exact and methodical in his teaching, clear and emphatic in his statements to the useful extent of even being somewhat dogmatic, he proved a highly successful expositor of the subject. The anatomy department in his earlier professorial days had a preponderating share in medical education, and the number of students of anatomy was large. Turner's genius for organisation accordingly found ample scope in the arrangement for teaching. He remained professor for thirty-six years, and it is a melancholy recollection that as 1917 would have represented fifty years since he first became professor, former pupils were already considering a jubilee celebration in his honour.

During the tenure of the anatomy chair Sir William Turner had shown, as a member of Senatus, so thorough a knowledge of university affairs, and, above all, so unequalled an ability to deal with financial problems, that he was an easy favourite for the principalship, in succession to Sir William Muir. He was appointed to this high office and also to that of vice-chancellor in I903. The one reservation that found expression in some quarters was the possibility that he might exhibit a bias in favour of medical interests. He, however, assumed office with the declared intention of acting always in the best interests of all the faculties, and he loyally carried out this intention. A retrospect shows how wholeheartedly he furthered the well-being and success of all the faculties. He has left his impress on the development of each of them, which has been so gratifying in recent years. He was largely instrumental in establishing new professorships and lectureships, and in furthering tutorial instruction in arts and science. With unflagging energy and much tact he pioneered schemes for new buildings and new technical departments. On the site of the famous old infirmary, monuments of his untiring energy have been erected for science and arts, rivalling in some respects the palatial buildings devoted to medical education, erected while he was professor of anatomy.

Turner did not confine his activities to university affairs. In 1886 he was appointed member of the General Medical Council, of which body he remained a member for nearly twenty years. On the resignation of Sir Richard Quain in 1898 he was elected president of the council. This high office gave him full opportunity for displaying the qualities of tact, organising power, and familiarity with details, not less than the skill in reconciling conflicting interests, by which he was so conspicuously distinguished. As the mouthpiece of the council he conveyed to the Privy Council the views of the medical profession and the medical authorities on all questions of public and State importance, and thereby his influence on the wellbeing of the medical profession and on medical practice in the British Empire became a preponderating one. He successively occupied many other high appointments, such as those of president of the Royal Society of Edinburgh, of the Royal College of Surgeons, of the Royal Physical Society of Edinburgh, of the Anthropological section of the British Association, and of this Association itself on the occasion of its meeting in 1900 .

Turner's business capacity led to his services being frequently in request on various committees and institutions affecting the public. Notwithstanding these many occupations, the almost unbounded vitality displayed during the greater part of life allowed him to do good and notable original work. He was one of the editor-founders of the Journal of Anatomy and a frequent contributor to its pages. His writings on anthropology and 